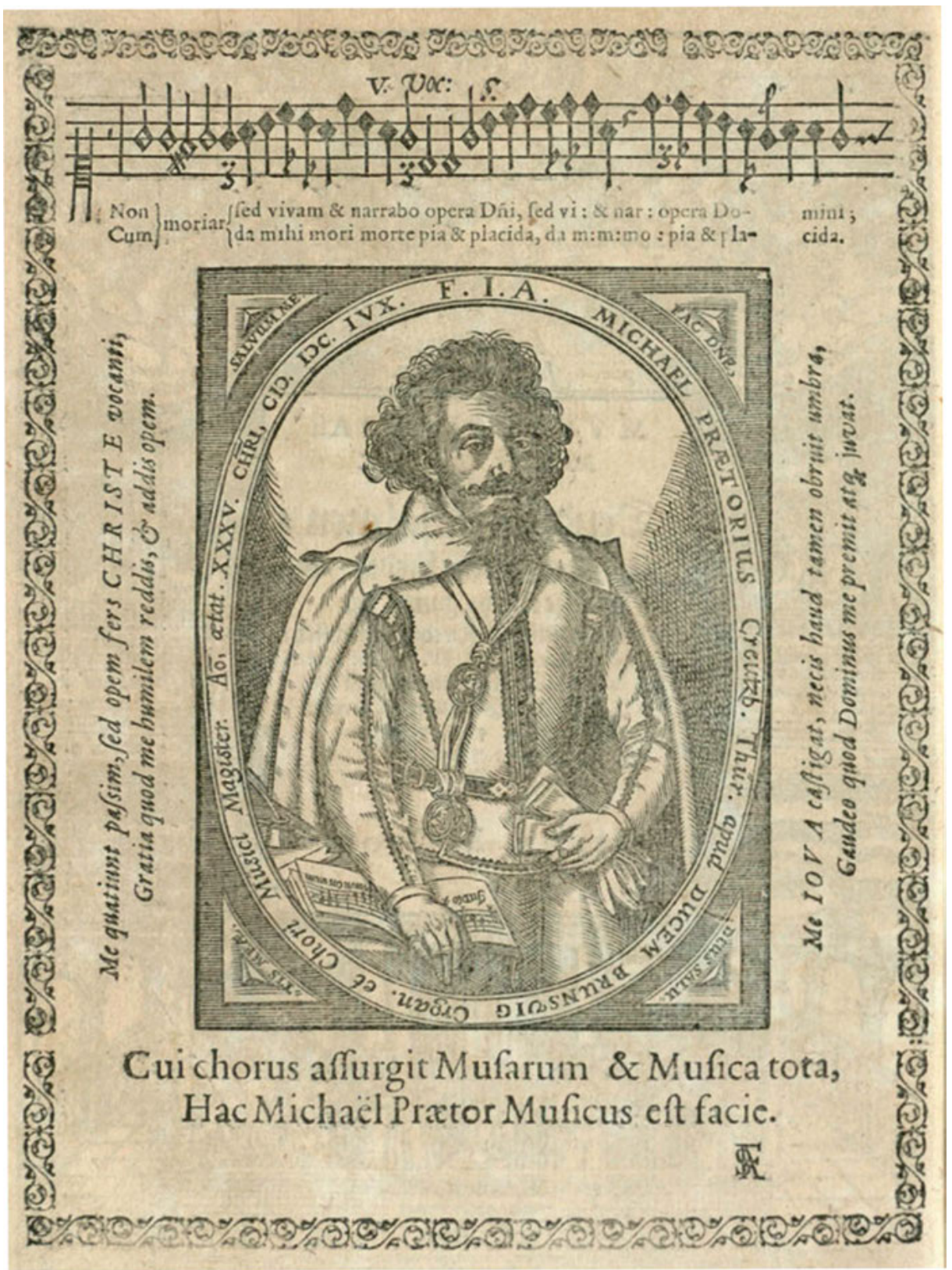

Fig. 20.1: Portrait of Michael Praetorius (1571-1621). General preface to Musae Sioniae (actually in Musae Sioniae I), The Royal Danish Library (Kongelige Bibliotek), Copenhagen.

Ә Open Access. () 2021 Beate Agnes Schmidt, published by De Gruyter. (c) BY-NC-ND This work is licensed under the Creative Commons Attribution-NonCommercial-NoDerivatives 4.0 International License.

https://doi.org/10.1515/9783110639452-021 


\section{Angels and the Muses of Zion: Michael Praetorius and Cultural Exchange between the Danish and German Lutheran Courts before the Thirty Years' War}

The chapter focuses on the vision of a New Jerusalem of sound as developed by the Wolfenbüttel composer and court master Michael Praetorius (1571-1621), and the role of this vision within a distinctly Lutheran cultural exchange between German courts and Denmark at the beginning of the seventeenth century. This cultural exchange, involving the giving of valuable musical instruments, musical books, and other gifts, solidified the dynastic relationships between the Danish court, the Dukes of Braunschweig-Wolfenbüttel, and Electoral Saxony. Praetorius used these relations to promote his music. However, unlike any of his contemporaries, he also infused this exchange with an aspirational theological, almost utopian interpretation of the role of music in sacred history, which he communicated through various texts. According to Praetorius, the practice and promotion of (good) music, especially sacred music, is inseparably linked to the heavenly city of God both in its current existence and with respect to God's eternal kingdom after the Last Judgement. Music in this eschatological sense as "music of Zion" furthers the future Jerusalem in preparing the believers for their role in the heavenly chapel and the eternal praise of the Lord. Good practice of music was thus a key prerequisite to achieve this vision. It had to be defended against philistines and the Calvinist critics of lavish music in church service. Praetorius believed that this message would be especially well received at King Christian IV's (r.1588-1648) court in Copenhagen.

In the essay On Worldly Government and Church Service prefacing his magnum opus Polyhymnia Caduceatrix \& Panegyrica of 1619, Wolfenbüttel court chapel master Michael Praetorius derives the patronage of music from generosity, a "virtue foremost proper and fitting for princes and high potentates." In his appeal for a generous "princely spirit" he points to the magnificent orchestra at the court of old Testament King David, who, together with Theodosius and Constantine, the first

Note: For critical comments and improvements I am grateful to Alexander Schmidt.

Beate Agnes Schmidt, Research Fellow, Historical Music Studies, Hochschule für Musik, Theater und Medien, Hannover, Germany 
Christian emperors of Rome, should be prime models for every Christian prince. ${ }^{1}$ Among the intended addressees of this message mixing self-interest with piety was also King Christian IV of Norway and Denmark, to whose court Praetorius would sent a gift copy of the Polyhymnia Caduceatrix \& Panegyrica. ${ }^{2}$ As Wolfenbüttel Hofkapellmeister and non-resident chapel master at Dresden, ${ }^{3}$ Praetorius benefitted throughout his career from the dynastic relations of his lords and patrons to the Danish court. Here Duchess Elisabeth of Brunswick-Wolfenbüttel (1573-1626), sister of King Christian IV, played a key role in maintaining this net of dynastic relations and the cultural and political exchange that went with it. Her marriage to Duke Heinrich Julius of Brunswick-Wolfenbüttel (1564-1613) in 1590 furnished multiple occasions for King Christian to visit Wolfenbüttel from 1595 onwards and to intervene in the politics of the duchy up to the 1620 s.

During his visits at his sister's court King Christian also took an interest in the construction works and the architecture of the new town quarters of Wolfenbüttel, which informed his planning in the re-foundation of Christiansstad in the then Danish province of Scania. The questions in the following will address whether the transfer of musical culture amounted to a real exchange or whether it was restricted to the same one-way path from Germany to Denmark as in the case of architecture. While the outlines of this cultural transfer, including the material objects exchanged between Praetorius and the Danish court are fairly well known, ${ }^{4}$ the symbolic meaning and context of gift-giving of musical prints and instruments to Christian IV in terms of both aesthetics and confessional politics have not been studied, even though Praetorius was perhaps the most influential German Lutheran composer before the Thirty Years' War.

My chapter here focuses on the symbolic meanings implied in the reciprocal gift-giving and in the celebration of joint festivities involving these two Lutheran courts. But the interest of this chapter goes beyond the examination of material

1 Michael Praetorius, Polyhymnia Caduceatrix \& Panegyrica (1619), ed. Wilibald Gurlitt, GA vol. 17 (Wolfenbüttel: Kallmeyer, 1930), VII-IX. Note that GA here and in following instances stands for Gesamtausgabe der musikalischen Werke.

2 Det Kongelige Bibliotek København, Musiksamlinger, mu 6602.2631 Box U260. Accessed February 12, 2019. http://www.kb.dk/da/nb/samling/ma/digmus/pre1700_indices/praetorius_polyhym.html.

3 On Praetorius's biography, see Siegfried Vogelsänger, Michael Praetorius - Diener vieler Herren (Aachen: Alano, 1991), Arno Forchert, "Musik als Auftragskunst - Bemerkungen zum Schaffen des Michael Praetorius," Schütz-Jahrbuch 27 (2005): 37-51; Wilibald Gurlitt, Michael Praetorius (Creuzbergensis). Sein Leben und seine Werke (1914/15), eds. Josef Floßdorf and Hans-Jürgen Habelt (Wolfenbüttel: Floßdorf, 2008).

4 On this particular connection, see Peter Hauge, "Praetorius's Connections to the Danish Court," in Michael Praetorius - Vermittler europäischer Musiktraditionen um 1600, eds. Arne Spohr and Susanne Rode-Breymann (Hildesheim: Olms, 2011), 33-49. For Praetorius as model-agent of cultural transfer see Arne Spohr and Susanne Rode-Breymann, "Michael Praetorius als Agent von Kulturtransfer in der Frühen Neuzeit. Eine Einleitung," in Michael Praetorius - Vermittler europäischer Musiktraditionen um 1600, ed. Arne Spohr and Susanne Rode-Breymann (Hildesheim: Olms, 2011), 15. 
exchange. My main emphasis lies with the theological, confessional, and political meanings that were implied in this exchange. Here this chapter argues that, based on his very personal vision of a celestial music, Praetorius developed an ideal of angelic polychoral church music that heralded a new Jerusalem and a heavenly Zion. This was not just an appeal to individual believers to prepare in this life for the eternal pleasures of serving the Lord as heavenly singers and musicians in the afterlife. His praise for the music so highly esteemed in his day is also an exhortation to patrons and rulers to promote and protect it against unbelievers and music critics. How important was Praetorius's ideal of a musical new Jerusalem in this exchange? What were his strategies of conveying his ideas? My aim is to discuss the venues of exchange and the patterns of musical-aesthetic and confessional-political argumentation in the context of Lutheran music writing in the early seventeenth century, and in the light of the cultural transfer between Praetorius and the Danish court.

\section{North German-Danish Connections}

Praetorius first came into contact with Christian IV and the Danish court chapel during the "guest performances" of individual chapel members accompanying the king during his stays in Wolfenbüttel. As prince of the North-German duchy of Holstein, Christian IV not only held a seat on the Bench of Princes in the Imperial Diet. Due to the skilful matrimonial politics of his father, Friedrich II of Denmark and Norway, was also in close dynastic relations with two influential Lutheran courts in Germany - that of Brunswick-Wolfenbüttel since 1590, and that of the Electoral Saxony since 1602.

From the very beginning, these dynastic relations of blood were smoothed by a shared interest in music, marked on Christian's side not just by patronage but also by the king's personal fondness for making music. At the Kronberg wedding ceremonies for Duke Heinrich Julius and Duchess Elisabeth, the king distinguished himself as proficient in playing the trumpet, the lute, the cornet, the violin, and the trombone. ${ }^{5}$ Concerts and other forms of musical performances were, of course, an integral part of courtly representation and accompanied all types of aristocratic festivities and diplomatic gatherings. ${ }^{6}$ The first major opportunities for Praetorius to present his music to

\footnotetext{
5 Count Heinrich Posthumus von Reuss, who was a guest at the wedding in Copenhagen, reports several musical talents of the king "and what is possible only for a great lord to learn." Heinrich Posthumus Reuß, Reiseerinnerungen aus der Zeit von 1593-1616, ed. Berthold Schmidt (Schleiz: Lämmel, 1890), 25.

6 King Christian IV visited Elisabeth for the first time in February 1595 to attend the baptism of Princess Hedwig of Brunswick-Wolfenbüttel. In return, Duke Heinrich Julius attended the coronation ceremony of the king in Copenhagen at the end of August 1596, to which he was not accompanied by Duchess Elisabeth. Hilda Lietzmann, Herzog Heinrich Julius zu Braunschweig und Lüneburg
} 
the king in person can be dated to 1595 and 1605 respectively: first, after his initial visit in February 1595, the young Danish prince returned to the Wolfenbüttel court of his brother-in-law in October of the same year. This second visit featured horseback stag hunts, fireworks, a tour of the city of Brunswick, and a stay at Gröningen castle near Halberstadt. ${ }^{7}$ Most certainly, Heinrich Julius had already introduced his recently hired chamber organist Praetorius ${ }^{8}$ to the king when Christian IV was shown the new, still-unfinished castle organ. ${ }^{9}$ The organ was considered an artistic marvel, equipped with 3000 pipes, 59 registers, and 26 pedals, which in total carried the hefty price tag of about 10,000 Reichsthalers. ${ }^{10}$ Just a few months later, in August 1596, Duke Heinrich Julius inaugurated the magnificent instrument with lavish performance testing, to which fifty-three famous organists from all parts of the Empire had been invited. Praetorius later extolled it as "a powerful work of art" that reproduced the sounds of all sorts of instruments: flute or barbiton, pipe or tambourine, battle horn or trombone, lyre or trumpets. ${ }^{11}$ The organ was one of the Duke's most renowned prestige

(1564-1613). Persönlichkeit und Wirken für Kaiser und Reich (Braunschweig: Selbstverlag des Braunschweigischen Geschichtsvereins, 1993), 26, 106, 14. There are no records suggesting the presence of Praetorius at these visits and at the oath-taking ceremonies in the city of Hamburg in October 1603. See Mara R. Wade, "Kulturtransfer durch Herzogin Elisabeth von Dänemark," in Herzog Heinrich Julius zu Braunschweig und Lüneburg (1564-1613), eds. Werner Arnold, Brage Bei der Wieden, and Ulrike Gleixner (Braunschweig: Appelhans Verlag, 2016), 272-82; on music as an integral part of the ceremonies at German courts in the late Renaissance see Jörg Jochen Berns, "Instrumenteller Klang und herrscherliche Hallräume in der frühen Neuzeit. Zur akustischen Setzung fürstlicher Potestas-Ansprüche in zeremoniellem Rahmen," in Instrumente in Kunst und Wissenschaft. Zur Architektonik kultureller Grenzen im 17. Jahrhundert, eds. Helmar Schramm, Ludger Schwarte, and Jan Ladzardzig (Berlin: de Gruyter, 2006), 527-55.

7 Anonymous, Verzeichnus der Reise / welche die Kön. May. Zu Dennemarcken Norwegen Anno 1595. Zu etlichen Jhren anverwandten chur vnd Fürsten in Teutschlandt angestellet (1595).

8 Praetorius was hired for the Duke's court chapel around 1594/95. He refers to his occupational beginnings in Michael Praetorius, Motectae et psalmi latini (1607), ed. Rudolf Gerber, GA vol. 10 (Wolfenbüttel: Kallmeyer, 1931), VIII, and Praetorius, Polyhymnia Caduceatrix \& Panegyrica, GA 17, XI.

9 Hauge, "Praetorius's Connections to the Danish Court," 40.

10 The largest pipes alone measured over nine meters and weighed more than 150 kilos. See Johann Georg Leuckfeld, Antiquitates Gröningenses (Quedlinburg: Calvisius, 1710), 80-86. On the organ, see Cristoph Albinus, Sacrvm magnificis laudibus reverendissimi illvstrissimi inter literatos potentißimi inter potentes literatißimi [. . .], (Wolfenbüttel: Konrad Horn, 1596), n.p.; Andreas Werckmeister, Organum gruningense redivivum: oder kurtze Beschreibung des in der grüningischen Schlos-Kirchen berühmten Orgel-Wercks (Quedlinburg: Struntz, 1705). To compare, the entire of budget of the Wolfenbüttel court in 1594 was 12,027 Reichsthaler, which paid for no fewer than 413 members of staff. Martin Ruhnke, Beiträge zu einer Geschichte der deutschen Hofmusikkollegien im 16. Jahrhundert (Berlin: Merseburger, 1963), 124.

11 Praetorius, Motectae et psalmi latini, GA 10, VII. 
objects. A contemporary poet compared it to the seven wonders of the ancient world, such as the pyramids and the famous mausoleum of Halikarnassus. ${ }^{12}$

On his second visit to his sister's court, Christian IV spent the traditionally music-filled Christmas and New Year's season from November 1605 to January 1606 in Wolfenbüttel. The diplomatic purpose of his trip was to mediate in the conflict between Duke Heinrich Julius and the city of Braunschweig. That the duke presented the substantial number of one hundred Reichsthalers to the musicians from the Danish court is an indication of both the large size of the accompanying orchestra and the impression it made on the duke. ${ }^{13}$ The duke's donation was also a visible sign of acknowledgement of Christian's efforts as a promoter of music, who, since his official accession as King of Denmark and Norway, had gradually built up his court chapel to rank among the largest orchestras of the European princely courts. It included Irish and Scottish harpists, singers from the Netherlands and from the Imperial court in Prague, as well as English violinists and lutenists, such as the famous John Dowland, who had been engaged at the Wolfenbüttel court up to $1596 .{ }^{14}$ According to Arne Spohr, the exquisite, almost exotically diverse composition of the Danish court chapel was informed by a similar princely emulation to assemble prestigious cabinets of curiosities from worlds of art and nature fashionable at the time. ${ }^{15}$ Christian IV was probably inspired by his brother-in-law Heinrich Julius, who had built up his ensemble along similar lines. Praetorius also alludes to the international composition of the Wolfenbüttel Hofkapelle in the epistle dedicatory prefacing the Motectae et Psalmi latini of $1605{ }^{16}$

There are no records of gestures of conspicuous gratitude by the king to the musicians at the Wolfenbüttel Court in the form of monetary gifts in the Danish accounting books. ${ }^{17}$ However, the king showed the princely virtue of liberalitas (generosity) towards the arts by giving a commemorative coin to Praetorius. The contemporary term Gnadenpfennig, literally penny of clemency, is a clear understatement. For this "penny" was in fact a golden medal of high material and symbolic value. When Praetorius

12 Christoph Albinus, Sacrvm magnificis laudibus reverendissimi illvstrissimi inter literatos potentißimi inter potentes literatißimi [. . .]. (Wolfenbüttel: Konrad Horn, 1596). Christoph Albinus extolls the almost transcendental effect of the organ's music on human hearing: "Angelicas audi quae Musica mulceat aures, | Orgia sunt, sanctis organa facta locis” (Hear how angelic music soothes the ear, I They are sensual revels, which are made by organs in sacred places).

13 Hannover, Niedersächsisches Landesarchiv, Hann. 75c A Nr. 36, fol. 268r.

14 Ole Kongsted, "Christian IV. und seine europäische Musikerschaft," in Europa in Scandinavia. Kulturelle und soziale Dialoge in der frühen Neuzeit, ed. Robert Bohn (Frankfurt a. M.: Peter Lang, 1994), 115-26.

15 Arne Spohr, "How chances it they travel?” Englische Musiker in Dänemark und Norddeutschland 1579-1630 (Wiesbaden: Harrassowitz, 2009).

16 Praetorius describes the court orchestra at Wolfenbüttel as a "chorus" composed of members from "various nations" (diversis nationibus). Praetorius, Motectae et psalmi latini, GA vol. 10 VII.

17 Hauge, "Praetorius’s Connections to the Danish Court," 40. 
commissioned a wood-cut portrait of himself for the edition of his Musae Sioniae (Muses of Zion) of 1605 it depicts the composer, who by 1605 had risen to the position of a court chapel master, wearing this kingly gift together with two other medaillons. ${ }^{18}$ The slightly higher Danish medallion is engraved with a picture of King Christian IV, ${ }^{19}$ while the two medallions below it display the Duke and Duchess of BrunswickWolfenbüttel. Their lower position also reflects their lesser status in the symbolic hierarchy of European princes (Fig. 20.1).

Since the later sixteenth century, such Gnadenpfennige were favoured as tokens of aristocratic representation and appreciation for subordinates. What the king rewarded Praetorius for exactly can only be subject to conjecture. Nonetheless, the valuable gift reflects Praetorius's rather extraordinary career, rising from an obscure organist and student of theology without a degree to become chapel master at the Wolfenbüttel court: indeed he was appointed, despite the fact that the position had already been held by Thomas Mancinus (died c.1612) and had thus by no means been vacant. ${ }^{20}$

Within the triangular dynastic connection between the courts of Copenhagen, Wolfenbüttel, and Dresden, Duchess Elisabeth, Praetorius's benefactress, played a decisive role. Through her, Christian IV held political weight over the Dukes of Brunswick-Wolfenbüttel, solidifying his sphere of political influence in North Germany and in particular in the Reichskreis of Lower Saxony, over which he presided as Kreishauptmann until his crushing defeat by Imperial forces in the socalled Kejserkrig from 1626 to 1629. The Danish king mediated in the Duke's conflicts with the city of Braunschweig and directly handled government affairs after 1615 as part of his tutelage for the underaged heir. The greatest political coup of the so-called Danish Court Party, ${ }^{21}$ which comprised Duchess Elisabeth, her brother Christian IV, and her brother-in-law Duke Philipp Sigismund (1591-1623), bishop of Osnabrück and Verden and dean of Halberstadt Cathedral, together with Duke Friedrich Ulrich, was the toppling of the aristocratic Territorial Regiment, the stewardship of Anton von Streithorst and other members of the estates over the duchy. ${ }^{22}$

18 Michael Praetorius, Musae Sioniae I (1605), ed. Rudolf Gerber, GA vol. 1 (Wolfenbüttel: Kallmeyer, 1928). The golden Gnadenpfennige have not been preserved. Praetorius's son of the same name later sold "golden chains, effigies and goblets" out of need, as he admitted in a letter to Duchess Sophia Elisabeth of Brunswick-Wolfenbüttel of 17 January 1655. Wolfenbüttel, Niedersächsisches Staatsarchiv, 3 Alt 325, fols. 21r-22v, here fol. 21v.

19 See One-Mark coins from 1606 and 1607: https://en.numista.com/catalogue/pieces80763.html; https://en.numista.com/catalogue/pieces80765.html, https://numimarket.onebid.pl/auction/1/cate gory/12164/lot/366?lang=en. All were accessed January 12019.

20 Gurlitt calls this appointment a "coup de force” by Duke Heinrich Julius. Gurlitt, Michael Praetorius (Creuzbergensis), 135.

21 On the influence of the Danish Party, Gurlitt, Michael Praetorius (Creuzbergensis), 145-48.

22 For a comprehensive account, see Julius Otto Opel, Der niedersächsisch-dänische Krieg, vol. 1 (Halle: Waisenhaus, 1872); Lietzmann, Herzog Heinrich Julius; for partial aspects, Oliver Auge, 
As Mara Wade has shown, Duchess Elisabeth was the central agent in the exchange of matters of art between her court and those of her siblings. ${ }^{23}$ It can be assumed that she helped Praetorius to establish contact with the Danish court, for he had become a personal favourite and confidante in the course of his tenure as organist and chapel master at the Wolfenbüttel court. ${ }^{24}$ That the Duchess left Praetorius the significant sum of 500 Reichsthalers in her will of 11 February 1618 testifies to his special position at the court rarely matched by other musicians at the time. ${ }^{25}$ Since the first biographical accounts of Praetorius in the early eighteenth century, there have been repeated claims that he had served as Elisabeth's official chamber secretary, ${ }^{26}$ yet there are no records to support this assertion. Their relationship, which became particularly close in $1608 / 09$ and continued up to at least 1618 , must have been of a rather informal nature of trust, shared intellectual and artistic interests, and favours. As a devout Lutheran, Elisabeth shared her passion for music and pious contemplation with Praetorius, who had started out as a student of theology, thus following the professional footsteps of his father and other members of a family of Lutheran pastors. Elisabeth, who, according to Praetorius, "loved the psalms in her heart," 27 also advocated decisively his calling to become a member of the convent of the secularized monastery of Amelungsborn, which was basically a sinecure. ${ }^{28}$

\footnotetext{
"Werner Arnold / Brage Bei der Wieden / Ulrike Gleixner (Hrsg.), Herzog Heinrich Julius zu Braunschweig und Lüneburg (1564-1613). Politiker und Gelehrter mit europäischem Profil. Beiträge des Internationalen Symposions, Wolfenbüttel, 6.-9.10.2013. (Quellen und Forschungen zur Braunschweigischen Landesgeschichte, Bd. 49.) Braunschweig, Appelhans 2016,” Historische Zeitschrift 305, no. 3 (2017); Jill Bepler, "Practical Perspectives on the Court and Role of Princes: Georg Engelhard von Loehneyss' 'Aulico Politica' 1622-24 and Christian IV of Denmark's 'Königlicher Wecker' 1620,” Daphnis 32 (2003): 137-163.

23 On the duchess's role as a cultural transmitter between the cognate courts of Copenhagen, London, Dresden, and Wolfenbüttel, see Wade, "Kulturtransfer durch Herzogin Elisabeth von Dänemark."

24 On Duchess Elisabeth and Praetorius, see Margaret Boudreaux, "Support in Trying Times: Michael Praetorius and Duchess Elisabeth of Braunschweig-Wolfenbüttel,” Choral Journal 58/9 (2018): 24-31.

25 Wolfenbüttel, Niedersächsisches Staatsarchiv, 1 Alt 27 No. 675.

26 According to these, Praetorius was the author better known as prior of the monastery Ringelheim and chamber secretary of Duchess Elisabeth ("Cammer=Secret. Fr. Elisabethen"), even before his position as a "Capellmeister." Johann Martin Schamelius, Naumburgisches Gesang-Buch (Naumburg: Boßögel, 1717), 57-58. See also Johann Caspar Wetzel, Hymnopoeographia, oder Historische Lebens= Beschreibung der berühmtesten Lieder=Dichter (Herrnstadt: Roth-Scholzen, 1719), 315-16; Johann Gottfried Walther, Musicalisches Lexicon oder musicalische Bibliothec (Leipzig: Wolfgang Deer, 1732), 491; and Carl Günther Ludovici, Grosses vollständiges Universal-Lexicon aller Wissenschaften und Künste (Leipzig: Zedler, 1741), 149.

27 Praetorius, Musae Sioniae I, GA 1, XIV.

28 Duke Heinrich Julius approved the vocation on 6 September 1608. Duchess Elisabeth and chamber secretary Heinrich Hartwieg negotiated the formalities and the details of Praetorius's official introduction with Abbot Antonius of Amelungsborn between 28 September and 8 October 1608. Wolfenbüttel, Niedersächsisches Staatsarchiv, 27 Slg Praetorius and Wolfenbüttel, Niedersächsisches
} 
Praetorius knew who he had to be grateful to. He dedicated two of his major works to the Duchess, not her husband, his lord. ${ }^{29}$ Especially in the Musae Sioniae I Praetorius consciously fashioned himself as a devoutly Protestant artist. With the inclusion of a portrait, personally chosen biblical sentences, a title woodcut, moral and religious mottoes, and symbols, this self-fashioning was unusually rich for a musician of his time. Praetorius combines these mannerist symbols of his persona with two short tracts in praise of music as an art: his own Greetings to the Churchmen and Friends of Music (Ecclesiastis et Philomusis Salutem), and one essay by no one less than Martin Luther from $1538 .^{30}$ This motive of self-fashioning also informs his 1608 re-edition of B $\rho \beta \varepsilon$ cıv. Ehrendanck: oder Aller Edlestes Kleinoth (Crown of Victory: Honorary Thanks, or Most Noble Precious), which he dedicated to Duchess Elisabeth. The work mainly contained sermons by his brother Andreas Praetorius of $1584,{ }^{31}$ to which he added two songs. The song "Mein Gott, mein Gott, o Vater mein" ("My God, my God, oh father mine") particularly underscores through an acrostic "MICHAEL" and his Symbolum Praetorius's personal identification with the Christological message of the text.

The dedications of Musae Sioniae VI-VIII to cloisters and schools in Lower Saxony, on the other hand, stand in the context of his calling to the convent of Amelungsborn. The dedicatees among princes and princesses are part of Elisabeth's dynastic relations and the wider Danish royal family, such as her sister Hedwig (Musae Sioniae II), her brother-in-law James I of England and VI of Scotland (Hymnodia Sionia), and perhaps also Prince-Elector Johann Sigismund of Brandenburg (Missodia Sionia) whose sister, Anna Katharina of Brandenburg, was married to Christian IV. Yet why did Praetorius never dedicate any of his printed works to the Danish king himself?

\section{The Muses of Zion}

Early works by Praetorius preserved in the Royal Library of Copenhagen testify to the fact that the composer wanted to return the favour and present the king with a valuable souvenir of their encounter. The Wolfenbüttel court chapel master sent King Christian IV his first five works, at the earliest in the summer of 1607, shortly

Staatsarchiv, 4 Alt 3 Amelb. No. 5481; see also Gurlitt, Michael Praetorius (Creuzbergensis), 168; Walter Deeters, "Alte und neue Aktenfunde über Michael Praetorius," Braunschweigisches Jahrbuch 52 (1971): 107-08.

29 The polychoral works of Motectae et Psalmi latini contained in a second edition of 1607 along with Musae Sioniae I are dedicated to Duke Heinrich Julius.

30 Praetorius, Musae Sioniae I, GA 1, VII-XI.

31 Andreas Praetorius, Ehrendanck: oder aller edlestes Kleinoth, ed. Michael Praetorius (Wolfenbüttel: Fürstliche Druckerey, 1608). 
after the publication of Motectae et Psalmi latini and Musae Sioniae $I I-I V .^{32}$ Peter Hauge has identified the white parchment cover and binding of the volumes as being of German-Dutch origin. The lilies and ornaments on the cover, he further claims, were most likely made sometime between 1610 and $1620 .{ }^{33}$ Praetorius's giftgiving practice of sending prints immediately after publication to an addressee, however, point to an earlier date, sometime between 1607 and 1608.

Praetorius's gift-giving must be understood in the context of advertising and sales strategies of musical prints in the early seventeenth century. ${ }^{34}$ As in the cases of book donations to the city-magistrates of Leipzig, Frankfurt/Oder, Danzig, Mühlhausen, Nuremberg, and Wismar, he sent out prints in close temporal proximity to their publication. Such gifts carried with them expectations by the donor to receive something in return, generally money. As it was normal for authors and composers to receive corresponding compensation from their addressees, these donations can rather be categorized as unrequested merchandise by our standards. Praetorius clearly followed this practice in the case of his debut works of 1607 and $1608 .^{35}$ However, the gifting of musical prints was not restricted to monetary purposes. As in Praetorius's donation to the Danish court, they could also serve as proof of the artist's mastery in composition, or as tokens of remembrance to sponsors marking special occasions.

Little is known about the cultural practice of hand-written dedications in complementary copies. As the copy of the Syntagma musicum I sent to the city of Nuremberg shows, even such more commercially intended "gifts" featured handwritten dedications by the author. ${ }^{36}$ Hauge's claim that Praetorius's “"private' beautifully handwritten dedication" to King Christian IV was evidence of "a closer, more personal relationship" 37 must hence be treated with caution. Its wording rather reflects the conventional pitch of the contemporary panegyrics of princes genre (Fig. 20.3):

SERENISSIMO, POTENTJSSJMO, AC Sapientissimo Principi ac heroi, D[omi]no Christiano. IV. [. . . ] Clementissimo meo regi ac Domino. hasce Musicarum compositionum meas primitias humilima animj deuotione offero Michaël Prætorius C.

32 The eight partbooks are contained in Box A 19.3000. Det Kongelige Bibliotek København, Musiksamlinger, mu 6602.2131-35 U260; they are also available online, accessed October 18, 2019. http://www.kb.dk/da/nb/samling/ma/digmus/pre1700_indices/praetorius.html.

33 Hauge, "Praetorius's Connections to the Danish Court," 44-45.

34 Stephen Rose, "The Mechanism of the Music Trade in Central Germany, 1600-40," Journal of the Royal Musical Association 130 (2005): 1-37.

35 Gurlitt, Michael Praetorius (Creuzbergensis), 167.

36 "Inclutae REIPVBLICAE Norimberg. Bibliothecae donat. offert Auctor.” (For the famous City-State of Nuremberg. Donated and presented to her library. The Author), Bayerische Staatsbibliothek München, 4 Mus.th.1249 b-1. Accessed October 10 2018. https://reader.digitale-sammlungen.de/de/fs1/object/dis play/bsb10527681_00002.html.

37 Hauge, "Praetorius's Connections to the Danish Court," 33-49. 
(To the most serene, mightiest, wisest ruler and hero, Lord Christian IV [. . . ], my most clement King and Lord, I offer these, my first musical compositions, with humble devotion. Michael Praetorius Creuzbergensis)

In the epistle dedicatory for Duke Heinrich Julius Praetorius identifies the magnificent polychoral Motectae et Psalmi latini as primitias. ${ }^{38}$ Likewise, a "primitias" dedication is found prefacing the Latin "Muses of Zion" in Motectae et Psalmi latini in the Danish copy of the cantus voices. These particularly met the need for courtly magnificence and representation in Baroque aristocratic houses, to the extent that the gift symbolically stood not only for gratitude to Christian IV but also for his royal taste and artistic appreciation.

The term primitias, however, can also comprise Praetorius's Musae Sioniae, ${ }^{39}$ which was bound up with the Motectae in the Copenhagen copy (Fig. 20.2). Despite its Latin title, this series of works was written in German and published in various places: the Musae Sioniae I were printed in Regensburg in 1605/06, the Musae

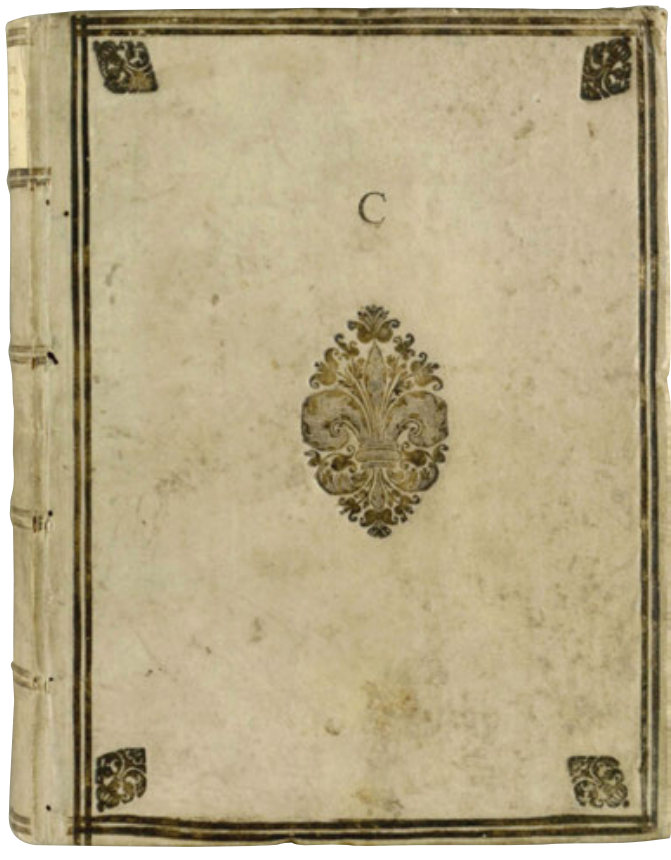

Fig. 20.2: Book cover, Cantus part from the Motectae et Psalmi latini and Musae Sioniae I-IV, The Royal Danish Library (Det Kongelige Bibliotek), Copenhagen. Sioniae II in Jena 1607 , and the Musae Sioniae III and IV in Helmstedt 1607. The term "muses of Zion" blending classical with biblical imagery became a programmatic label for the monumental series of spiritual choir music, including the later Musae Sioniae $V-I X$, which Praetorius was to launch in the following years. These Christianized protectors of the arts are represented by the angels that populate all titlepage woodcuts of his works.

Here, Praetorius utilized the motive of the new Jerusalem: the angelic muses symbolize the teleological and essentially divine character of music. The purpose of music, according to Praetorius, did not merely have an earthly purpose. It was made to furnish us for eternal life in divine grace,

38 Praetorius, Motectae et psalmi latini, GA 10, VIII.

39 Praetorius calls Musae Sioniae I-IV in Urania his "domahlige primitiae.” Michael Praetorius, Urania (1613), ed. Friedrich Blume, GA vol. 16 (Wolfenbüttel: Kallmeyer, 1935), VIII. 
in which every saved soul would joyfully celebrate the creator through songs and the playing of instruments. The perfected sound of celestial music in a heavenly Jerusalem was thus the Christian-platonic ideal, which earthly music should seek to approximate. Besides the support of Duke Heinrich Julius and his wife, Praetorius's encyclopaedic musical-religious project was also promoted by her sister Princess Hedwig of Saxony, who, like Elisabeth, cultivated her Danish connections and served as a significant agent of aristocratic patronage. The second volume of the German Muses of Zion is dedicated to Hedwig and adorned by her royal Danish coat of arms. ${ }^{40}$ Neither Danish princess used her husband's coat of arms. Instead, both Hedwig and Elisabeth favoured illustrations depicting the coat of arms of their nobler, royal dynastic origins. ${ }^{41}$ According to Mara Wade, both princesses shared clear religious intentions in their respective promotion of the arts. With Praetorius they supported "one of the composers most clearly identified with orthodox Lutheranism." Like her sister Hedwig, Elisabeth "embarked on a highly political and theological strategy for shaping the religious confession of her territories." 42

\section{Hidden Messages inside a Wooden Organ}

Aside from the commemorative coin and the donations of musical prints, there is a third item that testifies to Praetorius's connections to Denmark. During renovation works in 1692 a trilingual note by Praetorius was discovered hidden inside the organ at the castle of Frederiksborg near Hillerød. The wooden organ was another valuable gift to Christian IV by the Wolfenbüttel court. The Zettel is now lost but its content was copied in $1707 .^{43}$ To leave such "hidden" messages with information on the

40 Michael Praetorius, Musae Sioniae II (1607), ed. Rudolf Gerber, GA vol. 2 (Wolfenbüttel: Kallmeyer, 1939), VII.

41 See Elias Holwein, “Honestum pro patria”, Virtuelles Kupferstichkabinett, Herzog Anton Ulrich Museum, E Holwein AB 3.11 This resource is online, accessed February 2 2019. http://kk.haum-bs. de/?id=e-holwein-ab3-0011 (8.2.2019).

42 Mara R. Wade, "Widowhood as a Space for Patronage: Hedevig, Princess of Denmark and Electress of Saxony (1581-1641),” Renaessanceforum 4 (2008): 1-28.

43 Regarding the organ note, see Beate Agnes Schmidt, "Michael Praetorius manu propria. Persönliche Bekenntnisse und Wahlsprüche in Selbstzeugnissen,” Kirchenmusikalisches Jahrbuch 100 (2016): 70-72, 90-91, Wilfred Elsner, “Ein 'Höltzern Orgelwerck' für Herzogin Elisabeth," in Ruhm und Ehre durch Musik - Beiträge zur Wolfenbütteler Hof- und Kirchenmusik während der Residenzzeit, eds. Jürgen Habelt, Christoph Helm, and Rainer Schmitt (Wolfenbüttel: Kulturstadt Wolfenbüttel e. V., 2013), 83-100, Tekla Schneider, “Die Orgelbauerfamilie Compenius," Archiv für Musikforschung 2 (1937): 8-76, Povl Eller, “Compenius-Orgelets historie,” Dansk Årbog for Musikforskning 17 (1986): 7-51. 


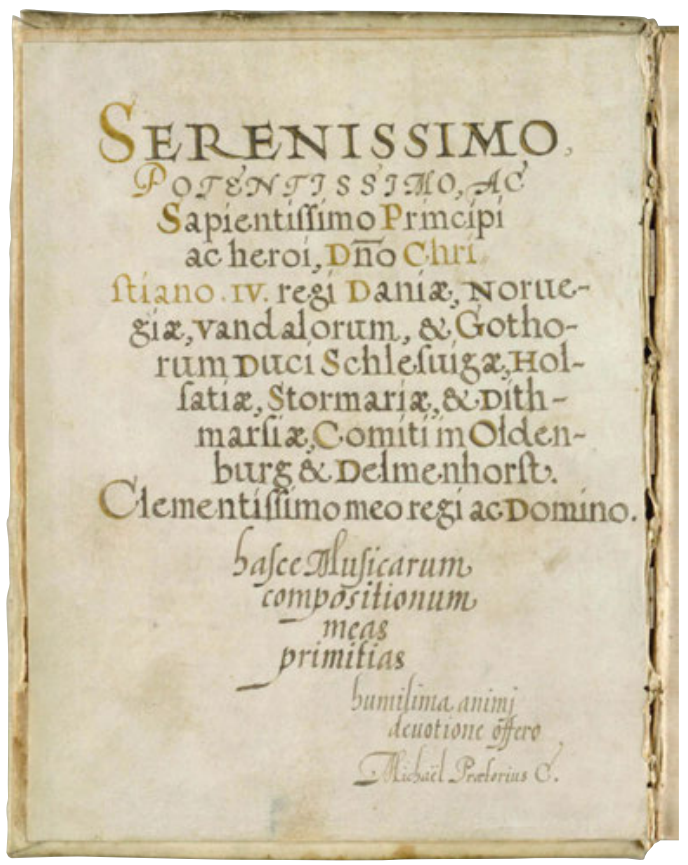

Fig. 20.3: Handwritten dedication to King Christian IV by Praetorius, Cantus part from the Motectae et Psalmi latini and Musae Sioniae I-IV, The Royal Danish Library (Det kongelige bibliotek), Copenhagen. construction have a long tradition in organ-building. ${ }^{44}$ The organ note contains production data as well as three chronograms referring to Praetorius's design and the year $1609 ;^{45} 7$ October 1610 is given as the date of completion by organ builder Esaias Compenius. Its obverse is written in Latin, while its reverse in German and Danish. The Danish translation must have been made around the time of the organ's transport from Schloss Hessen near Wolfenbüttel to Hillerød in August 1616. Duke Heinrich Julius is named as the commissioner of the organ (Figs. 20.4 and 20.5). ${ }^{46}$

Praetorius states his personal Symbolum (motto) here:

\footnotetext{
"Raptús amore Dei patiens dúrissima vinco

Nulla salús múndo: dulcis Mihi Patria Cœlum.”

(Captured by the love of God, I conquer, despite the hardest suffering

There is no salvation in this world: My sweet Home is Heaven.)
}

In Musae Sioniae I of 1606/07, Praetorius used a slightly different version of this motto for the first time in a printed work. It stands at the core of his self-image as a distinctively Christian musician and appears in all handwritten entries he left in

\footnotetext{
44 Praetorius mentions this practice of internally "hidden" messages, "Dingezeddel," and letters as well as inscribed surfaces in organs in Syntagma musicum II. Michael Praetorius, Syntagmatis Musici Michaelis Praetorï C. Tomus Secundus De Organographia [. . .] (Wolfenbüttel: Elias Holwein, 1619), 109-13.

45 The chronogram "VnICI nostrI reDeMtorIs" (VICIDMI = 1609) is given in the German and Danish translations as: "Im Jahr | In DeM wIer ChrIstVs | Heer (meaning "Herr") genennt seIn" and "aar effter | ChrIstVs DIn eenIste Mester | føtIs” (In the year we call Christ Lord).

46 Praetorius dates the completion to 1612. Praetorius, Syntagmatis Musici Michaelis Praetorii, vol. II, 189.
} 


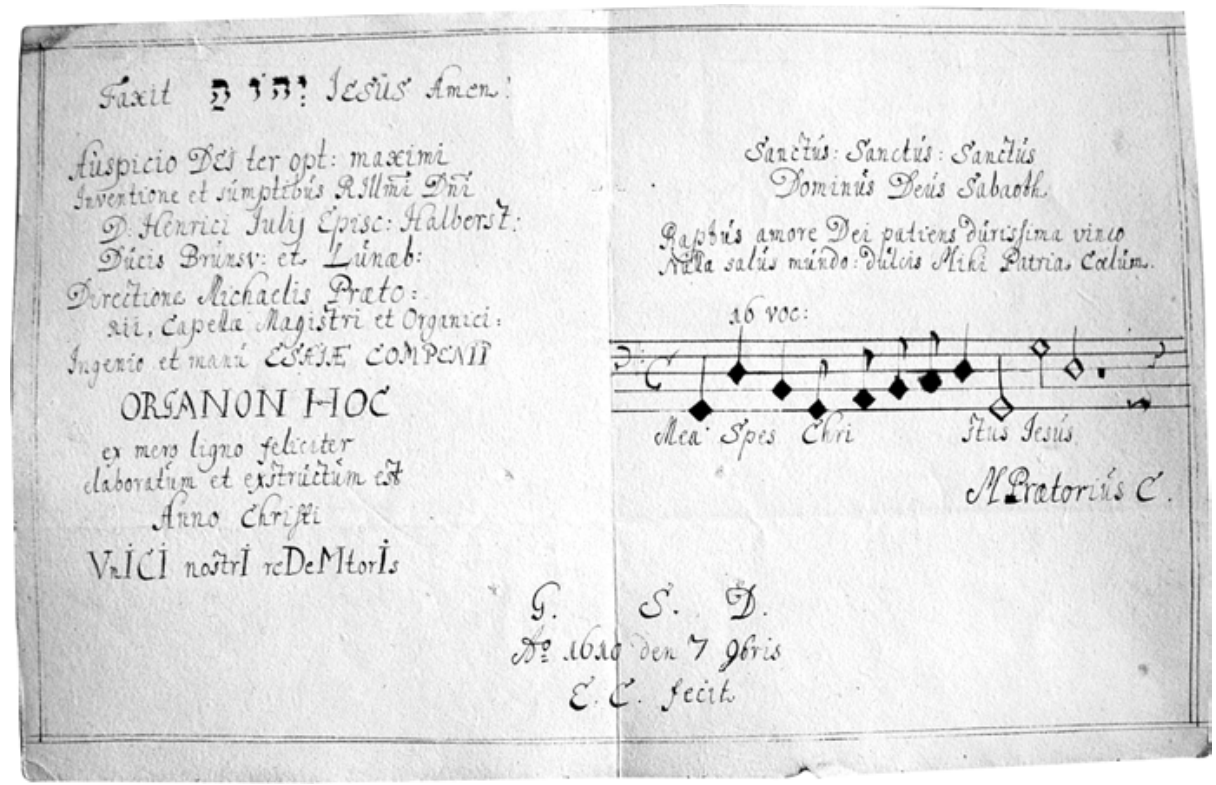

Fig. 20.4: Handwritten note by Praetorius found in the organ of Frederiksborg castle (front side), Copy from Peter Peterson Botzen (1707), The Danish National Archives, Copenhagen, Rentekammeret 2214.58.

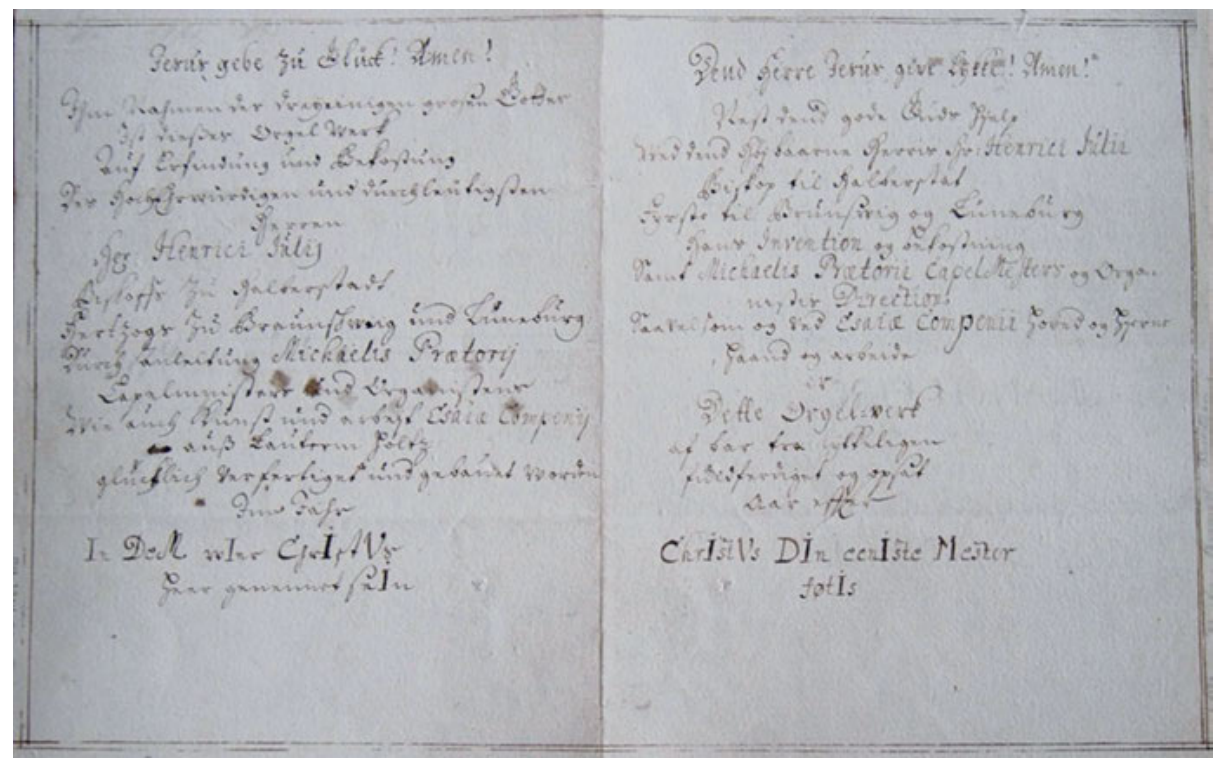

Fig. 20.5: Handwritten note by Praetorius found in the organ in Frederiksborg castle (rear side), The Danish National Archives, Copenhagen, Rentekammeret 2214.58. 
various Album Amicorum (book of friendship, Stammbuch, stambog). Praetorius had used the motto since 1603 and continued to do so until to $1619 .{ }^{47}$

In some instances, the motto may be connected to the simple "Mea Spes Christus (Jesus)" canon composed of triads. Likewise, the phrases "Faxit יהוה Jesus Amen!” and "Sanctús: Sanctús: Sanctús Dominús Deús Sabaoth” recur continually in his Stammbuch entries, as well as in his works and especially on title-page woodcuts. Praetorius uses these phrases and statements to express the central themes of his musical world view. They condense key ideas and recurring themes of Lutheran writings on music, which often combine confessional-political aspects in the praise of music.

That Praetorius would propagate his creed on a note left in an organ underscores the importance of this instrument to him as both instrumentalist and musical theorist. He lauds the organ in his writings as a far more celestial than mundane instrument. The largest parts of his writings on music are devoted to its provenance, construction, and function, and he records arrangements and timbres of all the organs he had inspected in the Central and North German lands. Apart from the construction of the majestic representative Gröningen organ, he also assisted in the building of the wooden organ in Frederiksborg Castle, which he tended between 1605/06 and 1610/12 together with Esaias Compenius. It is one of the few existing organs of the late Renaissance preserved. Originally, this organ was built for the private chambers of Duchess Elisabeth in Castle Hessen near Halberstadt and certainly accorded with her personal wishes and taste in art. ${ }^{48}$ With its 1001 pipes made of cherrywood, oak, walnut, maple, and pearwood - incorporating as well silver and ivory, contemporary slider chest techniques, and artistic inlays and carvings by Hermann van de Velde - the Frederiksborg wood organ is an exquisitely ornated piece of art and a very valuable status symbol. Despite its comparatively small size, it has an astoundingly compact resonance, the "strange/ gentle/ subtle sound and charm" which Praetorius could barely put in words. ${ }^{49}$

For him, the organ in general was the "queen of instruments," whose magnificent timbre would lift the hearts and the inmost devotion of men in today's churches, as it had done previously in the temple of Jerusalem in the times of Kings David and

47 Schmidt, "Michael Praetorius manu propria."

48 There was exchange between Duchess Elisabeth and Praetorius regarding organ-playing and construction. This is transmitted by Praetorius in paying the Hessian organist Georg Weisland for a repair job on her organ in early 1608. Wolfenbüttel, Niedersächsisches Staatsarchiv, 17 III Alt 68, fol. 76v; see also Gerhard Aumüller, "Esaias Compenius and his Family/Esaias Compenius og hans familie," in The Compenius Organ - Compenius-Orglet, ed. Claus Røllum-Larsen (Hillerød: Det Nationalhistoriske Museum, Frederiksborg Slot, 2012), 118.

49 On its disposition, timbre, and function as private chamber organ of Duchess Elisabeth see Praetorius, Syntagmatis Musici Michaelis Praetorii, vol. II, 141 (quoted), 89. 
Solomon. ${ }^{50}$ That the wooden organ from the Duchess's private chambers was chosen as a royal gift to Christian IV emphasizes not just the significance of their dynastic relations, but also its special symbolic value as an archetypal status symbol representing celestial music in the Lutheran understanding. Standing at the threshold, the organ sound was symbolically charged with a double eschatological meaning - it both resembled the music of the old Jerusalem temple and the perfect music of the New Jerusalem.

The reason for why this valuable possession was given away is stated by its maker, Elias Compenius, on a wooden block inside the organ: "The instrument remained at Hessen castle for over 5 years. It was donated by my gracious prince and lord, Duke Friedrich Ulrich, to His Royal Highness during the time of the second Braunschweig siege."51

In 1615 Christian IV made an extended visit to Wolfenbüttel to help settle an atrocious conflict dragging on since 1589 between the dukes and the semiautonomous city of Brunswick, which had recently flared up violently and was undermining the authority of the new Duke Friedrich Ulrich over his territory. The hereditary homage eventually paid to Friedrich Ulrich by the most powerful city within his lands, which had defied the authority of the dukes for many decades despite imperial decrees, was celebrated with magnificent solemnities in Brunswick on 6 and 7 February 1616.

\section{Music and Politics: A Ducal Visit to Copenhagen}

When Praetorius visited Copenhagen in May and June 1618, he was travelling in the retinue of Philipp Sigismund of Brunswick-Wolfenbüttel, Duke and PrinceBishop of Osnabrück and Verden. Duchess Elisabeth had entrusted him with a letter to her brother, Christian IV, which, however, has not survived. Evidently, it contained a message which had to be delivered by a person of trust. ${ }^{52}$ This exchange among members of the "Danish Court Party" must be understood in the wider context of Christian's ambitions to expand his sphere of influence in Northern Germany. Serving Christian's interests, Philipp Sigismund had secured the succession for the king's son Frederik II, later King Frederik III, to the

\footnotetext{
50 Praetorius, Syntagmatis Musici Michaelis Praetorii, vol. 11, 82.

51 "Alda hatt eß vber 5 Jahr gestanden, und in der andern Braunschwiegischen [!] belagerung, von meinem gnedigen fürsten v[n]d hern, Hertzogk Friedrich Vlrich etc. Ihr König Maÿ: vorehret worden." Mads Kjersgaard, "The Compenius Organ over 400 Years / Compenius-Orglet gennem 400 år," in The Compenius Organ - Compenius-Orglet, ed. Claus Røllum-Larsen (Hillerød: Det Nationalhistoriske Museum, Frederiksborg Slot, 2012), 141.

52 Braunschweig Stadtarchiv, Sacksche Sammlung, HV 191: Music Volume 1, 189-90 (Elisabeth of Brunswick-Wolfenbüttel to Praetorius, 26.4.1618).
} 
bishopric of Verden in 1618. On 12 March 1619, Duke Frederik, barely nine years old, became Philipp Sigismund's Coadjutor (co-ruler) in Verden and was later appointed to rule it as Lutheran Prince-Bishop from 1623 to 1629.

The appointment was preceded by Philipp Sigismund's visit to Copenhagen with state ceremonies lasting a number of days from 22 May to 15 June 1618. A further aspect of the visit concerned Philipp Sigismund's support for Christian IV to become his successor in the Osnabrück bishopric. ${ }^{53}$ The king knew how to display his gratitude. Philipp Sigismund received an almost royal reception opened by a military parade of horse- and footmen, "kettledrums and silver trumpets," which was followed by tournaments, displays of horsemanship, fireworks, banquets, and theatre plays. The celebrations were described by the royal court astrologer, theologian, and playwright Nicolaus Helvaderus (Niels Helvad, 1564-1634) in his famous Silva chronologica ${ }^{54}$ and by the Icelandic travel writer, canon, and adventurer Jón Ólafsson (1593-1679). The latter was particularly impressed by the solemn reception in Valby Bakke. Three musical bands in the royal tent, one composed of 24 trumpeters with gilt instruments, another composed of trombone, crumhorn, and shawm players, and a choir of singers, provided almost uninterrupted music during the visit, alternating between trumpeters, instrumentalists, and singers with "herlig firstemmig Sang” (wonderful song for four voices). ${ }^{55}$ The music was composed by the royal chapel master and student of the famous Venetian Giovanni Gabrieli, Mogens Pedersøn (1585-c.1623). ${ }^{56}$

The visit of Philipp Sigismund and Praetorius to Copenhagen occurred during what Ole Kongsted calls the "authentic flowering of the chapel royal," when, following the Danish victory in the Kalmar War, the Swedes filled the king's coffers with contributions. ${ }^{57}$ The fact that Praetorius brought musical instruments along to Copenhagen confirms the booming music culture of the day. ${ }^{58}$ He would certainly have met musicians like Hans Nielsen, another student of Gabrieli and violin virtuoso Johann Schop. Thanks to Praetorius's recommendation and sponsored by a grant by the Elector of Saxony, Dresden violinist Ambrosius Götze was able to study with Schop in $1616 .{ }^{59}$

53 Opel, Der niedersächsisch dänische Krieg, 1:60-61.

54 Nicolaus Helvader, Sylva chronologica circuli Baltici, das ist: historischer Wald- und Umbzirck deß baltischen Meers oder der Ostsee (Hamburg: Carstens, 1625), 302-03.

55 Jón Ólafsson, Oplevelser som bøsseskytte under Christian IV, ed. Julius Clausen, Memoirer og Breve 1 (Copenhagn: Gyldendalske, 1905), 93.

56 Kongsted, "Christian IV. und seine europäische Musikerschaft,” 115-26, especially 18.

57 Kongsted, "Christian IV. und seine europäische Musikerschaft," 122.

58 King Christian IV, note in his diary dated 14 June 1618: "Gav jeg Praetorius for nogle Instrumenter 224 Daler" ("I gave Prateorius 224 Daler for some instruments”), Christian Molbech, "Uddrag af K. Christian den Fierdes skrivecalendere," Historisk Tidsskrift 2/4 (1852): 251.

59 See the letter from Ambrosius Götze in Copenhagen to Elector Johann Georg, dated 15 March 1618, Dresden Sächsisches Hauptstaatsarchiv, 10024 Geheimer Rat, Loc. 7325/3, No. 115, fols. 304r-05r. 
King Christian IV showed Prince-Bishop Philipp Sigismund his magnificent castles and gardens in Copenhagen, Kronborg, and Frederiksborg. His appointed successor Duke Frederik accompanied them both throughout the visit. These celebrations were meant to solidify the political connections between Denmark and members of the Guelph dynasty, which were also informed by shared confessional values and interests. In the previous year Denmark had celebrated the centennial jubilee of the Reformation in the manner of Wittenberg and the rest of Electoral Saxony. In his tract Lutherus triumphans written on this occasion, Copenhagen theology professor and Bishop of Seeland, Hans Poulsen Resen, had left little doubt about who the enemies of the true Christian church were. Resen thereby aligned himself with his Dresden colleague, court preacher Matthias Hoë von Hoënegg, in his polemical attacks against the Papists, that is Roman Catholics, Calvinists, and Muslim Turks. ${ }^{60}$ The audience of a theatre performance at the conclusion of Philipp Sigismund's visit would thus have little difficulty in identifying who was meant by the enemies of Christendom in the play. Unfortunately, we neither know the text nor the title of this comedy written for this special occasion by Nicolaus Helvaderus. However, Jón Ólafsson later reported that the evil protagonists had been "the most frightful tyrants that ever existed, enemies of both God and Christendom, who were thrown into hell by a devil."61

In remembrance of these splendid celebrations he had witnessed, Praetorius sent the partbooks of the Polyhymnia Caduceatrix \& Panegyrica of 1619 to Copenhagen, which are still preserved in the Royal Library. ${ }^{62}$ They contain concerts performed at the Centennial of the Reformation in Dresden in 1617 as well as pieces written for other solemnities typical for court life, such as meetings of princes, princely baptisms, and weddings. Pieces from the Polyhymnia Caduceatrix \& Panegyrica were also performed in February 1616 during the magnificent celebrations marking the oath of allegiance celebrations in Brunswick as mentioned above.

60 Martin Schwarz Lausten, A Church History of Denmark (London: Routledge, 2016), 129-31; Jens E. Olesen, "Dänemark, Norwegen und Island," in Dänemark, Norwegen und Schweden im Zeitalter der Reformation und Konfessionalisierung. Nordische Königreiche und Konfession 1500 bis 1660, eds. Matthias Asche and Anton Schindling (Münster: Aschendorff, 2003), 85-92, especially 89: "His homage to Luther placed Resen in full agreement with German Lutheran orthodoxy, predominant above all in the Saxony Electorate and in Wittenberg University.”

61 "De graesseligste Tyranner, der har existeret, baade Guds og Kristenhedens Fiender, som af en, der agerede Djaesvelen, blev kastet ind i dette Helvede." Helvaderus was himself involved as an actor in the performance, playing one of the godless who were having a good time in hell with wine and food. He received sixteen golden thalers for writing and performing in the comedy. Ólafsson, Oplevelser som bøsseskytte under Christian IV, 1:96-97.

62 Det Kongelige Bibliotek København, Musiksamlinger, U260, mu 6602.2631. Accessed February 12, 2019 http://www.kb.dk/da/nb/samling/ma/digmus/pre1700_indices/praetorius_polyhym.html. Works from the Polyhymnia Caduceatrix \& Panegyrica had certainly not been premiered in Copenhagen. Praetorius would have mentioned the event for the record on the title page along with the other festive occasions. 


\section{In Praise of Music}

The pieces of evidence for this German-Danish cultural transfer in forewords, aphorisms, and iconography ${ }^{63}$ can be linked with themes of the Lutheran understanding of music as art with profound religious significance. In line with confessional-political policies of his Lutheran employers and sponsors, Praetorius combined his views on the importance of a varied and rich church music with an apologetic and polemical attitude towards a more restrictive understanding of spiritual music within the Protestant camp. He in particular fought positions advanced by Reformed theologians who objected to the use of instruments and to polyphonic vocal which was not written in the vernacular in church service. This Reformed emphasis on the simplicity and comprehensibility of music in church was already held by Huldrich Zwingli, but it became a bone of contention as a result of the colloquy held in Montbéliard between leading Lutheran and Reformed theologians, such as Jakob Andreae and Theodor Beza, in 1586. ${ }^{64}$ Against the more restricted Reformed understanding of church music as "neither required nor prohibited" (adiaphora or indifferent), Lutherans sought to re-evaluate musical expression in a much greater artistic diversity than the characteristic monophonic singing of the psalms practiced in Reformed churches. This defence of spiritual music against alleged impoverishment and barbaric austerity was at the heart of Praetorius's writings in praise of music, particularly in the Syntagma musicum. In general, the often satirical labels he coins for the critics and enemies of the art of music, such as amusos (unmusical), misomusos (antimusical), and zoili and momi (critical killjoys) in these texts are used without any specific reference. Yet in the Syntagma musicum $I$ he identifies these despisers of music as the Reformed Protestants or Calvinists. ${ }^{65}$

Enemies of music could also be defined by stereotypes based on standards of civilization instead of religious criteria, such as the Ottoman Turks and other "barbarians" with their "rattling and crowing shawms" ("schnarrenden vnd kikanden Schalmeyen"). According to Praetorius, there is no music in places "where the Devil rules / since the godless are unworthy of it. However, music is always held in high esteem by the true Church."66

63 On the title-page woodcuts and their iconography, see Ulf Wellner, Die Titelholzschnitte in den Drucken Michael Praetorius Creutzbergensis (PhD diss. Leipzig University, 2008).

64 Dietlind Möller-Weiser, Untersuchungen zum I. Band des Syntagma musicum von Michael Praetorius (Kassel: Bärenreiter, 1993).

65 Möller-Weiser, Untersuchungen zum I, 34; Michael Praetorius, Syntagmatis Musici Tomus Primus [...] (Wolfenbüttel: Johannis Richter, 1614/15), A2v; see also Schmidt, "Michael Praetorius manu propria;” Beate Agnes Schmidt, “'Lauter Berenhäuterey’? Heinrich Schütz und das Lob der Musik,” Schütz-Jahrbuch 40 (2018): 21-45.

66 "Da der Teuffel regieret / dann die Gottlosen sind deren nicht werth. Von der rechten Kirchen aber ist die Music zu jederzeit in hohem werth gehalten worden.” Praetorius, Syntagmatis Musici Michaelis Praetorii, vol. II, 83. 
Whoever would not practice music, he claimed, was unprepared for the sole occupation of the souls in heaven, that is making music, and had thus little chance to be admitted in the first place. Those ignorant of music would very likely later find themselves in the "hellishly hot chapel," where they would make a most terrible music as well as being deprived of the human voice, left only with the animalistic sounds of chattering teeth, howling, and bellowing. ${ }^{67}$

For Praetorius, the idea of the perfect music of Zion unites three aspects of understanding. First, it denotes the main occupation of the chosen in heaven in the sense of the church fathers Theodoret of Cyrus and St Augustine (De civitate Dei: 22, 40, 5). Second, he uses it as a central point of projection in his praise of the perfectibility of all music in this world. In line with a characteristically Protestant understanding of human history, Praetorius claimed that music in the current age had almost approximated heavenly music and thereby recovered the purity of music among the ancient Hebrews. Third, this vision of the afterlife has a deeply personal meaning for Praetorius as expressed in his motto Mihi Patria Coelum ("My Fatherland is Heaven").

In Lutheran thought the concept of a heavenly music formed a key inroad for themes from sacred history into more specific histories of music up to the late eighteenth century. Scholars writing in the genre had thus to integrate biblical history as well as questions about the Last Judgement and the end of the world into their histories. Between the creation and the end of the world, music in the Lutheran view of musical history does not appear static, on a constant plane, but rather "as progressus in the sense of advancement towards ever-higher musical quality." 68 For Praetorius this approximation to the eternal music of the angels had recently progressed so rapidly "that it is almost unbelievable." The secular idea of a constant perfection and refinement of the arts was taken from the civilizational models of humanist thought but connected to the narrative of sacred history. The refined music of his age was a "prelude and foretaste [. . .] of heavenly bliss," ${ }^{69}$ Praetorius claims. It almost equals that of the angels, as depicted on all his title-page woodcuts: in the first woodcut from 1607 (Fig. 20.6), the heavenly choirs in the upper half correspond in a very ordered way with the earthly choirs in the lower half; by contrast, on the woodcut from the Polyhymnia Caduceatrix \& Panegyrica of 1619 (Fig. 20.7), the boundaries between more realist depictions of musical practice and biblical figures, heaven and earth, are blurred with a characteristically Baroque abundance. According to Praetorius, the models of this near-celestial music on earth are twofold: first, the Venetian polychoral style as the most modern form of "singing per Choros," which was

67 Praetorius, Polyhymnia Caduceatrix \& Panegyrica, GA 17, VIII-IX.

68 Bernhard Jahn, “'Encomium musicae' und 'musica historica': Zur Konzeption von Musikgeschichte im 17. Jahrhundert an Beispielen aus dem schlesisch-sächsischen Raum,” Daphnis 30 (2001): 505.

69 “Vorspiel vnd Schmack [. . . ] der Himmlischen Frewde.” Praetorius, Urania, GA 16, VIII. 
"in truth, the proper celestial way of making music;"70 and second, the organ as "the sole truly spiritual Instrumentum Musicum" because one can "alternate and vary as in a poly-choral setting more than usual than on any other musical instrument."71

For Praetorius, the polychoral style represented the harmonious and polyphonic praise of God and its resonance on earth in terms of multi-layered tonal architecture and echo techniques. He traces the heavenly antiphony back to the prophecy of Isaiah (Isa 6:3). It also contains the Trisagion to the Holy Trinity: the "sanctus, sanctus, sanctus" of the organ note and title-page woodcut. For further proof of holy quality of the dual or polychoral style Praetorius points to Ps 87 , in which King David would praise the alternating antiphony between heathens and Jews born again "as in sacred Zion," and the vision of Ignatius of Antioch according to Cassiodorus's Historia tripartite, as well as the choral singing then in practice in convents and cloisters. $^{72}$

On both title-page woodcuts, Praetorius groups the choir of the "chosen blessed" to the left side of Mount Zion and the choir of "heavenly cantors, cherubim, and seraphim," among them King David, to the right. Their "shouts of joy" and their "many magnificent concerts" around the apocalyptic lamb, with cross-staff and Easter banner ( $\operatorname{Rev} 14$, see also Rev 4) cannot be anticipated on earth. However, the true believers can be prepared by singing spiritually like the Musae Sioniae - for the purpose of serving "there as blessed lay musicians" and,

gathered before his merciful throne in the new Jerusalem and heavenly Zion looking at him face to face and, with angelic and zionic songs of praise, in voices full of joy and heartful bliss together with all the holy cherubs and selected angelic choirs, being able to honour him, glorify him, and sing his praises. ${ }^{73}$

The polychoral concerts of the muses in the heavenly Zion thus provide the inspiration for the "Musis Sionijs Prætorianis" and lend their name to the Motectae et psalmi latini as Musae Sioniae latini and the German Musae Sioniae.

70 "dieweil die Art per Choros zu singen/ in Warheit die rechte Himmlische Art zu musiciren ist." Praetorius, Urania, GA 16, VIII.

71 "Denn die Orgel allein ein recht Geistlich Instrumentum Musicum ist; [. . . ] Do man vff zweyen/ vnd dreyen [. . .] Clavieren gar bequem/ artig vnd anmutig/gleich als per Choros vmbwechseln vnd varijiren, mehr als sonsten vff keinem Instrumento Musico geschehen kann.” Praetorius, Urania, GA 16, VIII. See also Praetorius, Syntagmatis Musici Michaelis Praetorii, vol. II, 82.

72 Praetorius, Urania, GA 16, VIII.

73 "Für seinem GnadenThron im newen Jerusalem vnd himlischen Sion versamlet/ ihn von Angesicht zu Angesicht anschawen/ vnd mit Englischen vnd Sionischen Lobgesängen in volliger freuden Stimm vnd Hertzens Wonne/ sampt den heiligen Frongeisterlein vnd ausserwehlten EngelChorn ehren/ preisen vnd rühmen mügen.” Michael Praetorius, Musae Sioniae V (1607), ed. Friedrich Blume, GA vol. 5 (Wolfenbüttel: Kallmeyer, 1937), VI. 


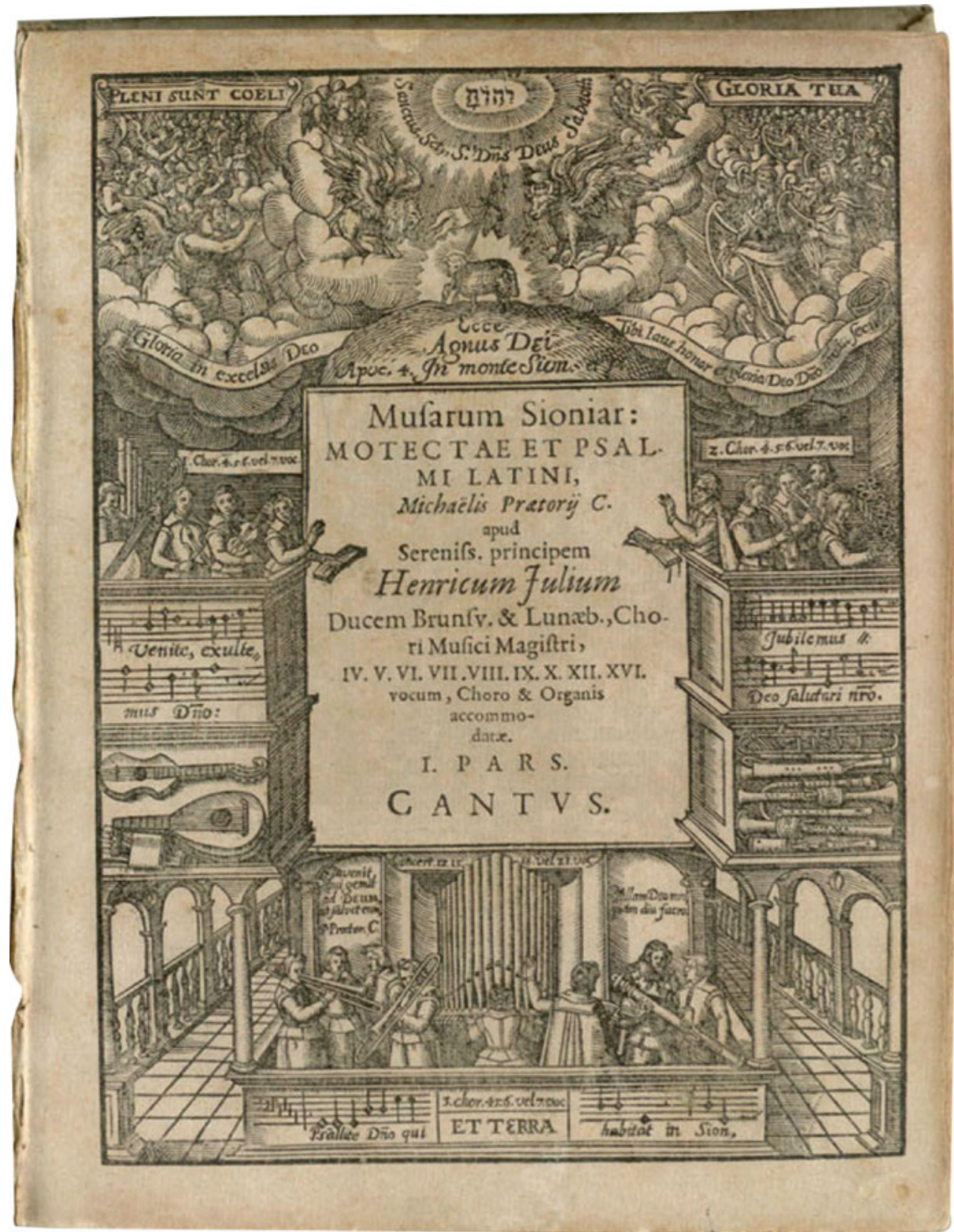

Fig. 20.6: Motectae et Psalmi latini, title woodcut, The Royal Danish Library (Det Kongelige Bibliotek), Copenhagen. 


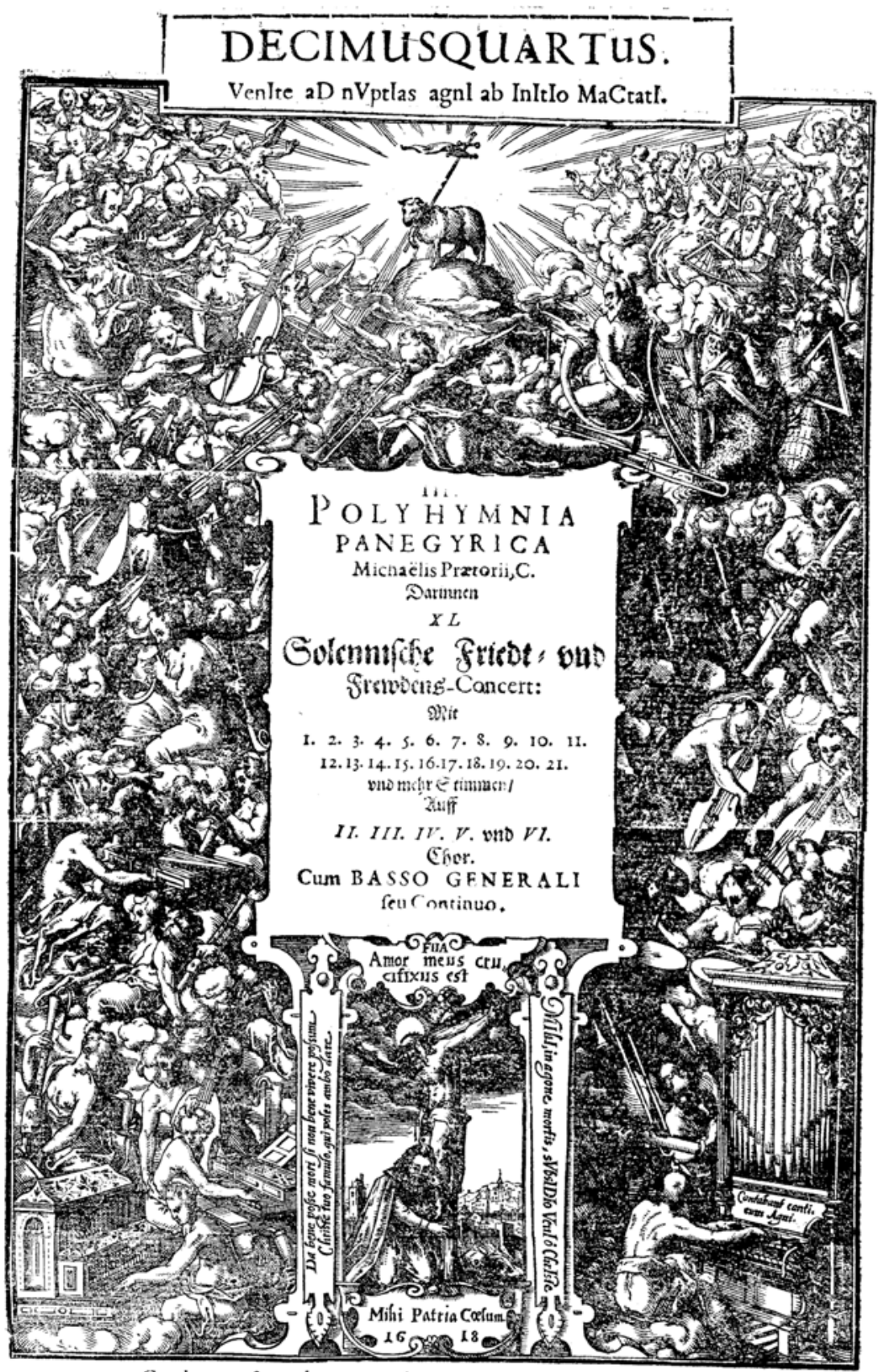

Gaudeamus \& exultemus, qquia venerunt NuP I IAE $\triangle G N L$

Fig. 20.7: Polyhymnia Caduceatrix \& Panegyrica, title woodcut, The Royal Danish Library (Det Kongelige Bibliotek), Copenhagen. 


\section{Praetorius “desired," he wrote}

to take his Musas and Gratias not from Pindus or Parnassus, but from the sacred and majestic mountains of Zion on which God is praised and honoured as the eternal great and highest by his beloved cherubs, who are then the real authentic and wisest muses and graces, with the happiest manifold pealing of bells in crescendo. ${ }^{74}$

With Johann Walter's Lob vnd preis der löblichen Kunst Musica (Tribute and praise of the commendable art of music) of 1538 the eschatological theme of the heavenly choir (Himmelskantorei) had become a leitmotif of early modern Lutheran writings on music. It was part of a wider frame of apocalyptic motives key to Lutheran religious culture and thought. ${ }^{75}$ Praetorius links the apocalyptic vision of heaven to Christology and his personal piety. On the woodcut that he commissioned for the Polyhymnia Caduceatrix \& Panegyrica (Fig. 20.7) he is depicted opposite a crowd of musicians in heavenly Zion, which are placed at the feet of the crucified Christ on Mount Golgotha with the silhouette of the city of Jerusalem in the back. Christ's cross becomes his own, which makes him a follower of the Saviour in his holy suffering. In line with Luther, Praetorius fashions himself as a humble imitator of Christ in his final moments on Mount Golgatha: "MIhI, in agone mortis, sVbsIDIo VenI ô ChrIste" (Come help me in the agony of death, o Christ!). The motive of the imitation of Christ receives a deeply autobiographical meaning because Praetorius takes stock of the fact that he was born in the small town of Kreuzburg (also written Kreuzberg or Creuzburg) near Eisenach. Though he only spent his early childhood in this town, he turns his place of origin into a part of his name by signing with the initial or the full spelling of M.P.C., that is Michael Praetorius Creuzbergensis. The latinized German Creu(t)zbergensis or Latin Crucimontanus, literally meaning originating from the mountain of the cross, infuses the factual statement about his place of birth with a highly religious significance. Praetorius links his earthly existence to Mount Golgatha, including his profession, for in some rarer instances the $\mathrm{C}$. in his initials also stand for "Capellmeister" (chapel master). ${ }^{76}$ For Praetorius, the Mountain of the Cross symbolizes his earthly life as a musician, which, as a "weighty procession and pilgrimage, week of crucifixion and torment" would soon be brought to an end. Like

74 "Seine Musas vnd Gratias nicht von dem Pindo oder Parnasso, sondern von dem heiligen vnd herrlichen Berge Zion nennen wollen/ Auff welchem/ gleich wie der ewige/ grosse vnd höchste Gott von seinen lieben Engelein/ welche dann die wahre/ rechte vnd allerweiseste Musæ vnd Gratiæ seyn/ mit vielfeltigem erhohletem frölichem Geleute/ gelobet vnd geehret wird.” Michael Praetorius, Musae Sioniae VII (1609), ed. Friedrich Blume, GA vol. 7 (Wolfenbüttel: Kallmeyer, 1939), VII.

75 On Lutheran eschatology, see Volker Leppin, “ . . . mit dem künfftigen Jüngsten Tag und Gericht vom sünden schlaff auffgeweckt’. Lutherische Apologetik zwischen Identitätsvergewisserung und Sozialdisziplinierung (1548-1619)," in Endzeiten. Eschatologie in den monotheistischen Weltreligionen, eds. Wolfram Brandes and Felicitas Schmieder (Berlin: de Gruyter, 2008).

76 See Schmidt, "Michael Praetorius manu propria," 82. 
many of his contemporaries in Germany in the decades around 1600, Praetorius experiences the present as a "peculiarly dangerous time," marked by war, disease and natural disasters. Like them, he reads these as a sign of God's wrath invoking the words of Luther: "The Last Judgement and the end of the world is at hand." Music and edifying songs of penance, however, could avert God's punishment. In this, he wants to follow in the footsteps of "his Lord of the Cross (CreutzHErrn), Jesus Christ" as his "CrossBrother," "until he enters the eternally triumphant church in heaven."77 This longing for heaven is reflected in his personal motto "Mihi Patria Coelum," which recurs in the organ note, in the statement of Musae Sioniae I, and on the title pages of Musae Sioniae II-IV. In line with the late Renaissance and Baroque obsession with the anagram, Praetorius also chose this motto because of the consonance of its abbreviation M.P.C. with his initials, Michael Praetorius Creuzbergensis. ${ }^{78}$

Praetorius identifies the magnificence of heavenly Zion as described in the prophecy of Isaiah and the Revelation by John as the model of church music - it was also the goal of his personal worldly peregrinatio as a composer and chapel master. He thereby combines the ideal of a heavenly choir (Himmelskantorei) with his praise of the progress or perfection in areas of music which are in particular rejected by the Calvinists as unsuitable for church service, such as the polychoral style and organ music. He claims that their perfection in his day would allow for a sensual glimpse of the grandeur of the celestial choir. ${ }^{79}$ Music, Praetorius contends in the Syntagma Musicum, was next to theology in dignity as a divine gift, since it is an "image and likeness of heavenly music." Because of its power to move, it has to be "taken more as of spiritual than a worldly essence," ${ }^{80}$ particularly in organ playing and in the antiphon of the angels, which anticipated polyphony.

Praetorius's promotion of church music draws its scriptural authority from the invocation of the chapel of King David, the "most supreme chapel master." Within the vision of heavenly music, Praetorius asserted, David was not just an individual saintlike model as a singer-priest playing the lyre on Mount Zion. The historical David had

77 Michael Praetorius, Kleine und grosse Litaney, ed. Friedrich Blume, GA vol. 20 (Wolfenbüttel: Kallmeyer, 1936), IX.

78 Central to the Christological motifs of his musical world view is Praetorius's canon "Mea spes Christus," which can be found on the Danish organ note as well as in his entries in various Album Amicorum (Stammbuch, Stambog). An alternative anagram playing with the initials of his name is “Mea sPes Christus.” See Schmidt, “Michael Praetorius manu propria,” 85.

79 Praetorius here refers to Girolamo Dirutas Il Transitivo (1593), see Praetorius, Syntagmatis Musici Michaelis Praetorii, vol. II, 88.

80 Praetorius, Syntagmatis Musici Michaelis Praetorii, vol II, 82. ("Von der dignitet vnd fürtreffligkeit der Orgeln/ vnd wie dieselbige alleine vnd sonderlich zum Kirchen- vnd Gottesdienst gerichtet/ allen andern Instrumenten vorzuziehen sey."). See Luther: "primum locum do Musicae post Theologicae," WA 30/2,696; also Christoph Krummacher, Musik als praxis pietatis: Zum selbstverständnis evangelischer Kirchenmusik, Veröffentlichungen zur Liturgik, Hymnologie und Theologischen Kirchenmusikforschung 27 (Göttingen: Vandenhoeck \& Ruprecht, 1994), 14-33. 
also presided over a magnificent chapel of 288 musicians in 24 choirs and 4000 "praise singers with stringed instruments," thus fostering polychoral practice as well as the playing of the organ and other instruments. ${ }^{81}$ Praetorius invoked David's chapel as the prime model for chapels at the princely courts of his day, thus addressing, in the first place, the Lutheran commissioners of the Polyhymnia Caduceatrix \& Panegyrica, Elector Johann Georg of Saxony, Duke Friedrich Ulrich of Brunswick-Wolfenbüttel, and Christian Wilhelm of Brandenburg, the Administrator of the Archbishopric of Magdeburg. Of course, Christian IV, who was also compared to David in the contemporary rhetorical genre of princely praise, would have very few difficulties in understanding the normative claim to follow the biblical king in his promotion of music. ${ }^{82}$

\section{Conclusion}

Why Praetorius never dedicated one of his major works to King Christian IV remains unexplained. Like Heinrich Schütz a few years later, his work certainly formed part of the "cultural flow to and from Denmark," 83 even though there is less evidence of the influence of Danish musical culture at the court of Wolfenbüttel than viceversa. I have discussed the confessional-political and musical-aesthetic significance of the gifts and solemnities for Praetorius's Danish relationships from the perspective of cultural transfer. The gifts to King Christian IV include significant objects such as the unique wooden chamber organ in Fredericksborg and the preponderant voluminous polychoral concerts which, from Praetorius's Lutheran perspective, were both associated with the celestial music of angelic choirs. In more practical terms, the heavenly choir of the singing and instrument-playing Muses of Zion served as an apologetic model in the defence of vocal and instrumental church music against misguided reforms. For Praetorius, King Christian IV, and many Lutherans of their time, Zion denoted a spiritual yet also practically relevant utopia, impacting princely politics, charity, and the arts. This utopia comprised three main dimensions of time: the biblical past of the covenant with God, the current rule of Christ in heaven, and the apocalyptic future of God's eternal rule after the last redemption. To imitate the model of the lyre-playing musician-prince was to take the path to this everlasting kingdom.

81 Praetorius, Urania, GA 16, VI-VII.

82 Mara R. Wade, German Court Culture and Denmark: The "Great Wedding" of 1634, Wolfenbütteler Arbeiten zur Barockforschung 27 (Wiesbaden: Harrassowitz, 1996).

83 Bjarke Moe, "Italian Music at the Danish Court During the Reign of Christian IV - Presenting a Picture of Cultural Transformation,” Danish Yearbook of Musicology 38 (2010/2011): 141. 